\title{
Corrigendum
}

\section{DRAM-3 modulates autophagy and promotes cell survival in the absence of glucose}

\author{
M Mrschtik, J O'Prey, LY Lao, JS Long, F Beaumatin, D Strachan, M O'Prey, J Skommer and KM Ryan
}

Cell Death and Differentiation (2017) 24, 1470; doi:10.1038/cdd.2017.57; published online 23 June 2017

Correction to: Cell Death and Differentiation (2015) 22, 1714-1726; doi:10.1038/cdd.2015.26; published online 1 May 2015

This article was originally published under NPG's License to Publish, but has now been made available under a CC BY 4.0 license. The PDF and HTML versions of the paper have been modified accordingly. (c) (i) This work is licensed under a Creative Commons Attribution 4.0 International License. The images or other third party material in this article are included in the article's Creative Commons license, unless indicated otherwise in the credit line; if the material is not included under the Creative Commons license, users will need to obtain permission from the license holder to reproduce the material. To view a copy of this license, visit http:// creativecommons.org/licenses/by/4.0/

(C) The Author(s) 2017 